\title{
Neutrophlic dermatosis (Sweet's syndrome-like) induced by paracetamol
}

\author{
M Teresa Dordal Culla ${ }^{1 *}$, Ramon Navarra Amayuelas ${ }^{2}, M_{\text {Teresa Martin-Urda Diez-Canseco }}^{2}$, \\ M Teresa Fernandez-Figueras ${ }^{3}$, Carles Lucas Giralt ${ }^{1}, M^{2}$ Mercedes Gomez Vazquez ${ }^{2}$ \\ From 6th Drug Hypersensitivity Meeting (DHM 6) \\ Bern, Switzerland. 9-12 April 2014
}

\section{Background}

Paracetamol (PC) is one of the most popular analgesics and antipyretics. It is generally considered a safe drug, although it can occasionally induce hypersensitivity reactions.

\section{Case-report}

An 82 year-old man with hypertension and ischemic heart disease underwent an inguinal hernioplasty. Twenty hours after initiating PC administration in the surgery room, a slightly pruritic eruption suddenly appeared with multiple tender, oedematous and erythematous plaques on the trunk and extremities, associated to general malaise, headache and myalgia. He didn't seek for medical care until 1 week later, when he came to the hospital for suture removal. No treatment was prescribed and the eruption resolved in 4 weeks. Two months later the patient developed, once again, a similar generalized skin eruption with fever $\left(38.5^{\circ} \mathrm{C}\right)$, general malaise and weakness. Neutrophilia (88.6\%) and elevated $\mathrm{C}$-reactive protein levels were detected. There was no mucosal or extracutaneous involvement. Few hours previously he had taken PC for a mild non-pyretic upper respiratory tract infection. The drug was withdrawn, and all signs and symptoms resolved after a short course of corticosteroid treatment. No evidence of active infection was detected. Histological examination of a skin biopsy specimen showed a neutrophilic infiltrate with mild eosinophilia, neutrophilic spongiosis and lichenoid damage. Five months later we performed epicutaneous patch test with PC in unaffected and previously affected skin, with negative results. The patient refused to perform more allergic studies. He had been tolerating

1Hospital Municipal de Badalona, Allergy Department, Spain

Full list of author information is available at the end of the article ibuprofen, metamizole and acetylsalicylic acid after the last reaction. Neither new episodes nor evidence of malignancy have been detected in the meantime.

\section{Observations}

The abrupt onset and type of cutaneous lesions, associated fever and neutrophilia, histopathological results, prompt response to corticosteroid therapy and drug withdrawal, and previous history of a similar reaction with PC intake, suggest a neutrophilic dermatosis (Sweet's syndrome-like) induced by PC.

\section{Authors' details}

${ }^{1}$ Hospital Municipal de Badalona, Allergy Department, Spain. ${ }^{2}$ Hospital Municipal de Badalona, Dermatology Department, Spain. ${ }^{3}$ Hospital Germans Trias i Pujol, Pathology Department, Spain.

Published: 18 July 2014

\section{doi:10.1186/2045-7022-4-S3-P83}

Cite this article as: Culla et al:: Neutrophlic dermatosis (Sweet's syndrome-like) induced by paracetamol. Clinical and Translational Allergy 2014 4(Suppl 3):P83.

Submit your next manuscript to BioMed Central and take full advantage of:

- Convenient online submission

- Thorough peer review

- No space constraints or color figure charges

- Immediate publication on acceptance

- Inclusion in PubMed, CAS, Scopus and Google Scholar

- Research which is freely available for redistribution

Submit your manuscript at www.biomedcentral.com/submit

\section{Biomed Central}

C Biomed Central

(c) 2014 Culla et al; licensee BioMed Central Ltd. This is an Open Access article distributed under the terms of the Creative Commons Attribution License (http://creativecommons.org/licenses/by/4.0), which permits unrestricted use, distribution, and reproduction in any medium, provided the original work is properly cited. The Creative Commons Public Domain Dedication waiver (http:// creativecommons.org/publicdomain/zero/1.0/) applies to the data made available in this article, unless otherwise stated. 